\title{
The Method of Pitt-Rivers
}

\author{
Alfred C. Haddon, A. Berriedale Keith , Alfred Nutt, Jessie L. Weston , A. \\ Werner , W. Crooke , E. Sidney Hartland , N. W. Thomas \& Walter W. Skeat
}

To cite this article: Alfred C. Haddon, A. Berriedale Keith, Alfred Nutt, Jessie L. Weston , A. Werner , W. Crooke , E. Sidney Hartland, N. W. Thomas \& Walter W. Skeat (1907) The Method of Pitt-Rivers, Folklore, 18:2, 217-248, DOI: 10.1080/0015587X.1907.9719775

To link to this article: http://dx.doi.org/10.1080/0015587X.1907.9719775

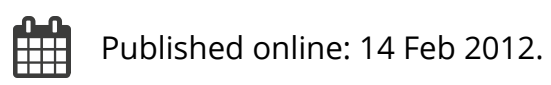

Submit your article to this journal $\sqsubset$

Џll Article views: 3

Q View related articles ¿ 
The Method of Pitt-Rivers,

The Evolution of Culture and Other Essays, by the late Lt.-Gen. A. Lane-Fox Pitt-Rivers. Edited by J. L. Myres, with an Introduction by Henry Balfour, 232 pp. 21 pls. Oxford : Clarendon Press. 1906. 7s. 6d. net.

From the beginning of the second half of the nineteenth century, evolution was, so to speak, "in the air." As Professor Tylor (Researches into the Early History of Mankind on the Development of Civilization, 1865; Primitive Culture, 1871), applied the evolutionary method to the thoughts and customs of mankind, so Colonel Lane-Fox (afterwards Lt.-General Pitt-Rivers) applied them to the handicrafts of man. Originally he investigated the evolution of firearms, and was led to believe that the same principle of extremely gradual changes, whereby improvements were effected, probably governed the development of the other arts, appliances, and ideas of mankind. We are told that as early as $185 \mathrm{r}$ (that is eight years before the publication of the first edition of The Origin of Species), with characteristic energy and scientific zeal, he began to illustrate his views, and to put them to a practical test; but it was not till 1867 that he published the first of his three epoch-making essays on "Primitive Warfare." These were followed in 1874 by papers read before the Anthropological Institute on the "Principles of Classification" and "Early Modes of Navigation"; the final paper of the series "On the Evolu. tion of Culture," was read before the Royal Institution in 1875. There are many students who have been influenced 
indirectly by the investigations and hypotheses of Pitt-Rivers (to give him the name by which he will be known to posterity) who have not actually read his papers; it was, therefore, a happy idea of our Oxford colleagues to take the opportunity of the establishing of a diploma in Anthropology in the University of Oxford to republish them in a convenient form, in order to supply the needs of candidates and of the numerous visitors to the Pitt-Rivers Museum in Oxford; and they are right in considering that they will "appeal to a far wider public as a brief and authentic statement of their author's discoveries."

The volume opens with an Introduction by Mr. Henry Balfour, which also formed the main portion of his Presidential Address to the Anthropological Section of the Cambridge Meeting of the British Association in 1904. No one is better fitted to expound the views of the founder than is the present Curator of the Pitt-Rivers Museum, who not only continues and extends the original collections, but has published several model papers on similar lines based upon careful investigations and upon the specimens with which he has enriched the Museum. Mr. Balfour, in his exposition of the methods of Pitt-Rivers, warns us that "it must not be supposed that he was unaware of the danger of possibly mistaking mere accidental resemblances for morphological affinities, and that he assumed that because two objects, perhaps from widely separated regions, appeared more or less identical in form, and possibly in use, they were necessarily to be considered as members of one phylogenetic group.... The association of similar forms into the same series has, therefore, a double significance. On the one hand, the sequence of related forms is brought out, and their geographical distribution illustrated, throwing light, not only upon the evolution of types, but also upon the interchange of ideas by transference from one people to another, and even upon the migration of races. On the other hand, instances in which two or more peoples have arrived independently at similar results, are brought prominently forward, not merely as interesting coincidences, but also as evidence pointing to the phylogenetic unity of the human species, as exemplified by the tendency 
of human intelligence to evolve independently identical ideas when the conditions are themselves identical. Polygenesis in his inventions may probably be regarded as testimony in favour of the monogenesis of Man." These remarks are as applicable to folklore as they are to technology.

Very wisely, the essays have been reprinted substantially as they were first delivered and published, only verbal errors and actual misquotations having been corrected. On the other hand, one cannot help feeling that the editor would have done well, either from his own store of learning or with the help of others, to have drawn attention in footnotes to statements which do not represent the present state of our knowledge. To take a very few examples, there is no evidence for supposing a relation between the coil and broken coil ornaments of New Zealand and New Guinea, still less that they "were probably derived from Assam" (p. 15). A zoologist experiences a sensation of pain when he reads of an "armadillo" in East Africa (p. 66). A note might have been added of the occurrence of a curved missile stick among the Hopi (p. 131). An additional argument in favour of the view "that the wamera preceded the bow" (p. 133) may be found in bone spearthrowers of palæolithic age from French caves. Reference might have been given to the considerable amount of work that has been done of recent years concerning the "Copper Age" (p. I57 ff.), the same also applies to the distribution of spirals (p. 172). As no references are given to more recent literature, readers who are ignorant of all that has been done on these lines during the last quarter of a century will be inclined to take the suggestions of Pitt-Rivers as the final word on any subject. At all events a note of warning should have been made by the editor.

Perhaps I may be permitted a personal allusion. Somewhere about 1878, either just before or after I had taken my degree, I came across, I cannot remember how, an illustrated account of an evolutionary series by Lane-Fox, of which my zoological, embryological, and palæontological studies at once enabled me to appreciate the importance. It was not till a decade later that the opportunity occurred for me to contribute anything 
on the same lines, and I shall never forget the pleasure it was to me to trace the degeneration of a human-face design on the canoes of Torres Straits. Nor shall I readily forget the thrill which I experienced when I first visited the PittRivers Museum at Oxford, and every visit that $I$ have since paid has resulted in stimulation and information. It is, therefore, with much pleasure that $I$, in common with so many colleagues, acknowledge the scientific acumen and indefatigable energy of the Founder of Comparative and Evolutionary Technology.

Alfred C. Haddon.

Adonis, Attis, Osiris. By J. G. Frazer, D.C.L., LLD., Litt.D. Macmillan \& Co. 1906.

Destined to form part of the third edition of The Golden Bough, this book has all the characteristic merits of that vast work. The greatness of the author's erudition is concealed by a vivid and fascinating style which, especially in the descriptions of the scenery of Asia Minor, reaches a high order of merit. On the other hand, it must be admitted not to be free of the main defects of The Golden Bough, a certain lack of discrimination in weighing evidence, and a tendency to draw important conclusions from scraps of evidence utterly insufficient to bear the structure reared upon them.

This tendency appears very clearly in the most novel part of the book, the attempt to show that in the rituals of Adonis, Attis, and Osiris, the place of the god was at one time regularly taken by the king, who was put to death in order that the god, by casting off his old body, might regain his strength. This is a serious proposition, and marks a considerable advance on primitive conceptions of the corn-spirit. It is no doubt true that many peoples have held that at harvest-time the cornspirit may pass into a man, and in some-we need not suppose in the majority - of the cases, have gone so far as to kill the human incarnation of the spirit, in order to make the corn grow well in the coming year. But a great gulf lies between this 
primitive custom and the annual sacrifice of a king-priest. By the time that Adonis, Attis, or Osiris had become the gods of communities, and bore these names, and received the ministrations of priests, they had long ceased to be nere corn or vegetation spirits, and it was no longer easy to regard the priest as the temporary incarnation of the corn-spirit.

Now, in fact, the evidence for any such death of the priestking in these cults is the weakest possible (see pp. 12, 29, 34, $38,85,182,314)$. In the case of Adonis it consists of the stories of the burning of Sardanapalus, Croesus, Dido, the son of Mesha of Moab, and of Hamilcar, and the walking of the king of Tyre amidst the stones of fire which Ezekiel records, as compared with the burning in effigy of Melcarth at Tyre and Gades, and of Sandan at Tarsus. But whether we regard the burning of an effigy of the god as a sun-spell, as is perhaps most probable, - the connection of the lion with Melcarth and Sandan is significant (see J.H.S., I90I, pp. 149, 161)-or as merely purificatory (see pp. 100, 151), the mere use of an effigy proves nothing. Mesha burned his son, as did the Carthaginians their children, as the greatest sacrifice he could offer to an offended god. In the case of Sardanapalus, Croesus, and Hamilcar, we have no doubt the same idea, probably combined with the conception that fire purifies the soul and bears it to the gods. The Dido story points to no more than the burning of an effigy, and it is not ' easy to see how the widespread practice of walking unharmed over cinders can be derived from a practice of burning alive. Further, it should be noted that we have no satisfactory evidence that the kings who worshipped Adonis were his priests, or deemed themselves incarnations of the god, or considered their children as gods. Dr. Frazer's evidence (p. 32) for this rests on accepting as descriptions of the descent of the bearers such names as Abi-baal, but this conjecture is as improbable as it is ingenious. Moreover, a king may claim descent from a god, as did Mesha, without thereby meaning that the godhead is in him incarnate, however much sanctity he may derive from his origin.

In the case of Attis, the evidence is still less convincing. To find a royalty bearing the name of Attis, utterly unknown 
in Phrygia, recourse has to be had to Atys of Lydia. To find a slain priest, appeal is made to a conjecture of Professor Ramsay's that the priest of Cybele named Attis was probably slain each year. From the story of Marsyas is deduced that the form of death was hanging, and from the "Havá-mal" verses, where Odin claims to have won his divine power by hanging for nine nights on the gallows dedicated to himself, that the hanged man was also a god. It is obvious that the "Hava-mal" proves nothing for actual ritual, and is merely a piece of speculation of the kind so frequent in the Brahmanas, which, however, are not yet seriously quoted as evidence in such cases. The Marsyas legend is probably a record of a very old vegetation-ritual, but it has nothing to do with the slaying of a king. Marsyas is no prince or priest, and the story proves no more than the occasional slaying of the human embodiment of the corn-spirit. For Osiris we have nothing save the interpretation of the Sed festival given by Prof. Flinders Petrie, as to which it is perhaps enough to say that it rests on the acceptance of the theory here discussed, and cannot be extracted from the record without the use of very considerable imagination.

While we cannot accept Dr. Frazer's pet theory of the annual hanging of a man-god on the sacred tree, we readily accept the proofs he brings forward for showing that the gods whose character he discusses were vegetation-spirits. That is not to say that they were merely such spirits, or originally deities of vegetation. Attis seems, from the evidence cited by Dr. Frazer himself (p. I79), to have been a Phrygian Zeus, who may, like Zeus himself (see Cook, Class. Rev., 1903), have aç̧urred vegetative functions, or have been syncretised with a vegetation deity. Melcarth and Sandan have characteristics of sun-gods, and in the case of Osiris we incline to accept the view that the god was originally the sun, the importance of whose worship in the Mediterranean has been recently established by Dr. Eıans (J.H.S., 1901). This view explains, quite as well as Dr. Frazer's theory, the mourning for the god at the summer $s$ istice (p. 228); and the nocturnal festival of Sais, instead of $14 \mathrm{k}$ a feast of all souls (p. 24r), shows signs of being a sun s..ell in the use of illumination and in the symbolism of the goluen sun 
between the horns of the Isis-cow. The yellow face of the image of Osiris in the feast in the month Choiak, and the use of a mould of gold, point to the same fact, and we may suggest as an alternative to Dr. Frazer's readjustment of the Egyptian festivals (pp. 263-267) that there were really two festivals which tended, as usual in Egypt, to syncretise, one in November, the season of sowing, and one at the winter solstice, originally a sun-spell like the Mahavrata of the Vedic ritual.

Dr. Frazer remains a convinced adherent of matriarchy, signs of which he sees in the predominance of the goddess in the cults in question, and from which he explains the marriage of sister and brother, long usual in Egypt, and also the legends (p. 28) of incest by kings. In the latter case, it is significant that Erechtheus and Clymenus are among the guilty. The legends, we think, are nothing more than echoes of the cosmic incest of heaven and earth familiar in Vedic and other mythologies. That female deities mean matriarchy is most improbable (see Farnell, Cults of the Greek States, iv., Iro), and under patriarchy sister-marriage might be regarded as the best form of marriage, in that it gave the greatest purity of blood, and prevented the waste of the family property in the purchase of a wife for the son, or of a husband for the daughter. For Semites and Phrygians, matriarchy remains a most improbable hypothesis.

Of the many other problems suggested by Dr. Frazer, it must suffice to note his view of Hyacinth as a hero (p. 207; see Farnell, iv., 264), and the theory that the blood used in purification from murder is accepted as a substitute for the blood of the slayer, with which should be compared the much more probable view of Dr. Farnell (iv., $3^{\circ 4}$ ) that the blood is that of a sacred animal, and so confers community and friendship with the angry god of the earth and lower world. Nor do we think it possible to accept the theory (p. 97) that the Sandon-Hercules of Lydia was a Hittite god, or that this people were akin to the primitive stock of Asia Minor (cf. p. 17). The facts available show similar religious conceptions all over Asia Minor, and probably generally in the Mediterranean area, and the worship should be assigned, if to any people in particular, to 
the Mediterranean race. So far as it goes, the linguistic evidence tends more and more to prove that the Hittites were an offshoot of the Aryan race; and it would be quite legitimate, on Dr. Frazer's authority, to cite as Aryan their worship of the bull (p. 47).

A. Berriedale Keith.

Royal Irish Academy: Todd Lecture Series: Vol. ix. E. Gwynn: The Metrical Dindschenchas, part $i i_{2}-$ Vol. xiii. K. MEYer : The Triads OF IRELAND.-Vol. xiv. K. Meyer: The Death Tales of the Ulster Heroes. Dublin: Hodges, Figgis \& Co., 1906.

THE foregoing volumes are all valuable contributions to our knowledge of early Irish literature, the interest of which, as I need scarcely remind readers of this journal, lies in the fact that it is the oldest post-classic European literature, and that it has preserved for us a considerable mass of themes and incidents very slightly, if at all affected by the Christian classic culture which has so profoundly influenced all the great modern literatures. To the student who wishes to get away from and behind that culture, Irish literature is one of the chief sources of information. It follows, however, that in regard to any freshly published Irish text one of the first questions that arises is to what extent it is independent of, and older than, the Christian classic tradition. For some time to come critical analysis must hold the first place in the discussion of new Irish material.

Professor Mejer's Triads of Ireland will be a revelation to many familiar, by repute, with the Welsh Triadic literature. Here again dependence of Wales upon Ireland, probable in other branches of literature, seems most probable. Professor Meyer has omitted all comparison between his texts and the better known Welsh collections. I would suggest to some member of this Society, Miss Faraday for instance, that a comparative study of these two bodies of gnomic wisdom together with such Northern examples as Havá-Mal, would be equally interesting and valuable. 
Professor Meyer dates the collection he prints from the middle of the ninth century. The bulk of the 256 numbers which it comprises are gnomic, but it is significant that the first 56 numbers are in the nature of mirabilia, are topographical in character, and are closely connected with the heroic sagas and ecclesiastical legends, which form such a large part of early Irish literature. The following may be cited as a characteristic example of early Irish wisdom :

"Three slender things that best support the world; the slender stream of milk from the cow's dug into the pail; the slender blade of green corn upon the ground, the slender thread over the hand of a skilled woman." Professor Meyer notes that the triad is only one of "several enumerative sayings common in Irish literature," and he believes that the "model upon which these were formed is to be sought in the enumerative sayings of Hebrew poetry, to be found in several books of the Old Testament." I cannot at all agree. Professor Meyer recognises that "triads occur sporadically in the literature of most nations . . . but I am not aware that this kind of composition has ever attained the same popularity elsewhere as in Wales and Ireland." Precisely. But then, assuming for one moment the correctness of the theory that makes Celtic dependent upon Hebrew literature in this respect, the question surely arises why the Celts alone should have developed the Triadic form. Proverbs and Ecclesiastes were as open to Italians and Frenchmen, to Englishmen and Germans, as to Irishmen and Welshmen. But the latter have a Triadic literature, the former have not. Why? Professor Meyer mentions, only, however, to reject: "the idea that the Triad owes its origin to the effect of the doctrine of the Trinity upon the Celtic imagination." He does right, in my opinion, to reject this idea, but does it not point towards the true solution of the problem? Was not the doctrine of the Trinity commended to the Irish wise men precisely because it fell into the mould of their own traditional wisdom? In using the shamrock illustration was not Patrick adapting himself, as a successful teacher must, to the intellectual habits of his hearers? As a matter of fact we know, what Professor Meyer should 
surely have noted, that the scanty remains of Greek information concerning the Celts do testify to the existence of Celtic Triads long before any Celtic people could have come in contact with Hebrew wisdom. The weakness of Professor Meyer's theory of origin is most apparent when one turns to the alleged Hebrew originals. The Book of Proverbs is the chief source; but, as most readers of Folk-Lore are certainly aware, the vast bulk of the sentences contained therein (at least $9^{8}$ per cent.) are not triadic in form. There are not more than half a dozen genuine triads in the whole book (and these, strange to say, are not quoted by Professor Meyer), besides a certain number which are really tetrads: "there are three things . . . and four things." Now this latter form not only produces a very striking literary effect, but the sayings which are cast in it are among the most memorable, and are certainly the best-remembered, of the collection. Why should the Irssh have neglected the duad form of the vast majority of the Hebrew sentences, have neglected the impressive tetrad form, have fastened upon just the half a dozen inconspicuous examples of the Triad? Why, indeed, unless that form were already familiar to them?

Professor Meyer further refers to a collection entitled Proverbia Grecorum, Greek sayings translated into Latin before the seventh century by, as their editor conjectures, an Irish scholar in Ireland. If this conjecture is correct, and Professor Meyer approves it, I hold that it strongly supports the native Irish origin of the triadic form. For this is almost unknown to the bulk of Greek proverbs, and if we find it largely represented in a version due to an Irish scholar, it can only be because the latter recast the Greek sayings in a form familiar to himself.

I note, lest it might escape the attention of students of the Ossianic cycle, that in No. 236, a "marvel" triad, the first wonder contains a quatrain from an Ossianic poem. If this number belongs to the original collection ascribed by Professor Meyer to the ninth century, this is one of the earliest testimonies to the saga of Finn and his warriors. The second and third marvels are examples of the "kelpie" belief; the lake monster in early Ireland has the same characteristucs as in living liaelic peasant belief. 
I warmly commend the volume, the price of which is only 2s. 6d., to the attention of all folk-lorists.

Professor Gwynn's Metrical Dindschenchas, part ii., is, in reality, his third publication devoted to these poems, the importance of which, for Irish myth and saga, is so great. As will be remembered, it was in the pages of Folk-Lore that any considerable mass of the prose Dindschenchas was first made public by Dr. Whitley Stokes. Until all the metrical forms have been published, it would be unsafe to dogmatise concerning the relations between verse and prose, but I may say that so far as the materials for comparison are available, they negative, in my opinion, the hypothesis that the existing prose collection is based upon or represents a verse one of equal extent, of which the Book of Leinster poems are the surviving fragments. Of the eighteen poems contained in the present volume, three are ascribed to the well-known tenth-century poet, Cinaed ua Hartacán. I would direct the special attention of students interested in the Etain story to a poem of Cinaed's (LL 209, 625), referred to by Professor Gwynn, p. 95, and a translation of which I owe to his kindness, in view of its bearing upon the remarkable fragments of the missing opening of the legend printed by Dr. Stern (Zeitschrift für Celt. Philologie vol. v., pp. 522-534), and commented upon by myself (Revue Celtique, vol. xxvii., pp. 325-339).

It is, however, the third of the above-mentioned three volumes that brings out most prominently the interest of Irish material for folk-lorists and the complexity of the problems it raises. Among the five tales edited and translated by Professor Meyer, I would single out those of the deaths of Conchobor and Celtchar. The former has been the best known hitherto of these stories, but the printing of all available versions throws new light upon the problems involved. As is well known, the death of the famous Ulster king is brought into connection with that of Christ, thus affording, perhaps, the most marked example of the wide prevailing Irish tendency to save the kings and heroes who were so dear to the native heart, by associating them in some way with the new faith. The texts, which have transmitted the story to us, contain at least three, if not more, varying 
accounts, two of which at least, vouched for by twelfth-century MSS., are obvious efforts to bring an existing story into accord with what the scribe knew of Roman history in the time of Christ. As it stands, the story falls into two parts : the wounding of Conchobor by the Connaught champion Cet with the brain-ball of the Leinster chief Mesgegra, in consequence of which he remained for seven years in a state of invalidism; his death when, angered at the tidings of Christ's crucifixion, he neglects the physician's warning, exerts himself violently, the brain-ball starts from his head, and he dies. Now one of the latest of the MSS. containing the story has preserved a poem by Cinaed úa Hartacán (who died in 975), which gives the history of the Mesgegra brain-ball. After Conchobor's death it seems to have remained hidden until its existence was revealed by the King of Heaven to Buite mac Bróhaig, abbot of Monasterboice (who died circa 520). "Since Bute with grace of fame has slept upon thee (i.e. the brain-ball) without treachery, the hosts have eagerly humbled themselves, until thou changedst colour, $O$ stone," says the poet. Now Cinaed's verses (dating as they must do from the tenth century) presuppose the story as it is found in the Book of Leinster (twelfth century) and later MSS., but, obscure and tortuously allusive as they are, are quite incapable of having originated it. They alone, however, enable us to divine its genesis and development. Early in the sixth century a stone, hallowed by traditional association with the famous Ulster king, was annexed by a partisan of the new faith, and thereafter acquired fresh virtue and credit. Concerning the king there was a tradition of a seven years' death-in-life trance, a theme found elsewhere in Irish tradition, e.g. in connection with Nuada of the silver hand and with Cuchullin, and undoubtedly in my opinion of mythical signifcance and origin. Some coalescence of the two stories took place, and, the Christianisation of Bute's aforetime pagan stone combining with the desire to preserve Conchobor from the fate to which a purely Pagan king would be liable, the existing story arose and grew. But, it may be asked, how could Mesgegra's brain-ball, an object that could be slung from a sling, and obtain lodgment in a mortal skull, an object no 
bigger, one would think, than a golf or tennis ball, serve as "Bute's pillow," to use the poet's words? Well, the very text which has preserved Cinaed's poem, has also preserved a short poem by the eleventh-century Flann Manistrech, in which gigantic stature is attributed to the old saga heroes; the length of Conchobor was seventy-three feet, of Tadg mac Céin (a famous third-century Munster chief), fifty feet. To my knowledge this is the earliest precise allusion in Irish literature to the giant size of the men of the heroic age, a conception widely spread throughout the Ossianic literature of the thirteenth and following centuries, but quite absent, at least stated in express terms, from the Ulster heroic sagas themselves. I conceive that it may possibly be the outcome of traditional connection between the racial heroes and the Megalithic monuments; the euhemerising antiquaries, of whom Flann is an excellent type, argued from the size of the quoits, wash-pots, whetstones, etc., which folk-fancy assigned to the heroes, that the latter must have been giants.

Still more interesting is the Celtchar death story. We learn that Blai of Ulster, a keeper of one of the guest-houses famous in Irish saga, was under geis to exercise the droit du seigneur on every woman who came to his guest-house unless her husband were in her company. Celtchar's wife, who seems to have been a mischief-maker, went alone to Blai. Celtchar, incensed at the wrong done him, pursued Blai even to the royal house, where Conchobor and Cuchullin were playing at fidchell, and speared him, so that a drop of the blood fell on the fidchell board. The drop being nearer Conchobor, it fell to the king to take vengeance. Meanwhile, Celtchar escaped to the Munster Déisi. The Ulster warriors were greatly troubled; it was bad enough losing Blai without having strife with the Déisi. The king suggests that Celtchar's son should go for his father, and be his safeguard, "for at that time, with the men of Ulster, a father's crime was not laid upon his son, nor a son's crime upon his father." Celtchar is very indignant at this move; his son ought to be kept out of the affair altogether, and in any case cannot, he feels, be a satisfactory safeguard for him. However, he returns, and has it laid upon him to free Ulster 
from the three worst pests that would come in his time. Conganchness, brother of Curoi (slain by Cuchullin, as is told in another story), comes to avenge the latter, "he devastated Ulster greatly; spears or swords hurt him not, but sprang from him as from horn." In his extremity Conchobor calls upon Celtchar. The latter offers his daughter to Conganchness, and she beguiles the latter into revealing how alone he may be slain. Thus was the first pest overcome. The second was the Dun Mouse, found by the widow's son in the hollow of an oak, and reared by the widow till big; then it turned upon the widow, slew her sheep and kine, herself and her son, and, thereafter, every night would devastate a liss in Ulster. Celtchar boils a $\log$ of alder in honey and fat until it was soft and tough; armed therewith he seeks the Dun Mouse's lair, and when the monster fixes its teeth in the tough wood, Celtchar passes his hand through the log and takes out its heart through its jaws. A year after three whelps are found in the cairn in which Conganchness was buried ; ${ }^{1}$ one was given to Mac Datho, and figures in the story of Mac Datho's Boar; one, Ailbe, was given to Culand the Smith; and one, Doelchu, was retained by Celtchar. But one day it was let out, and every night it would destroy a living creature in Ulster. Conchobor calls upon Celtchar to destroy this third pest. The latter obeys, slays it with his famous venomous spear, the luin, but in raising the spear a drop of the hound's blood runs along down, goes through him, and he dies.

Now here we have three or four well-known folk-tale themes set in the framework of the Ulster heroic cycle. At what time did this take place? The story must, be it noted, be pretwelfth century, as it is contained in the Book of Leinster. Can we trace it farther back? One of the three whelps of the Dun Mouse, Ailbe, was, we have seen, given to Culand the Smith. Now, Culand's hound is well known from the tale of Cuchullin's Boyish Exploits, embedded in the oldest version of the Tain bo Cualgne, in which it is killed by that hero

\footnotetext{
1 The implication, I have no doubt, although it is not expressed in the story, is that the Dun Mouse is in reality an avatar of Conganchness, come back in this form to avenge his slaying by treachery.
} 
when only seven years of age. The scribe of the eleventh century MS., the book of the Dun Cow, comments that Culand's hound cannot have been one of the three sprung from Conganchness' cairn; the latter's death, he justly remarks, happened long after the Tain in which Cuchullin is stated to be seventeen years old, and, therefore, necessarily long after the latter's slaying of Culand's hound which he asserts, moreover, came from Spain.

From these facts the following inferences may, I think, be fairly drawn. There were independent stories connected with Ailbe, one associating him with Celtchar and Culand, one with Culand and Cuchullin; the latter, owing to its inclusion in the Tain, became the more famous. But the other continued to be told and copied in spite of its inconsistency with that systematisation of the saga chronology which took place after, some time in the seventh century, the Tain assumed substantially its present form, and attracted to itself a number of other Ulster sagas. That the Celtchar death-story was not thus attracted and modified affords strong presumption that, substantially, it antedates the literary fixation of the Tain in the seventh century. And in this case the folk-tale themes in question must be far older on Irish soil. They may be added to the score of such themes which I have already detected in pre-eleventh century Irish saga literature. And, like the majority of the other instances, they occur in such a way as to preclude the hypothesis of recent alien origin.

Alfred Nutr.

Thomas' “Roman de Tristan." Edited by Joseph Béder. 2 vols. 1902, 1905. (Société des Anciens Textes Français.)

The publications of the Societe des Anciens Textes Francais, excellent as they are, appeal as a rule to but a limited circle. If M. Bédier's edition of the Tristan makes a wider claim, the reason is to be found less in the merit of the work, though 
that is great, than in the intensely human interest of the subject-matter. Thanks to the genius of Richard Wagner, we have learnt at last to recognise the legend of Tristan and Iseult as one of the world's great stories, the supreme lovetale of literature. M. Bédier, with true French insight, lays his finger on the reason-the legend deals with two enduring facts of life, Love and Sorrow. Tristan and Iseult are not the lovers of that lax social order which found expression in the Courts of Love, but belong to a stage wherein marriage is looked upon as indissoluble, and illicit passion, even though it be decreed by Fate, a shame and a sorrow. Neither of the lovers ever suggests cutting the Gordian knot by flight; they deceive Mark, steadily and persistently, and though at the moment they rejoice in the success of each deception, their joy is mixed with sorrow: "ils souffrent de leurs triomphes même." "Ceuxlà seuls peuvent fonder tout un poème sur la loi sociale hostile a l'amour, qui connaissent une loi sociale fortement impérative, rigide et dure." We think $M$. Bédier is right in his contention that it is this underlying, fate-compelling background which gives to the story of Tristan its enduring force and charm.

Whence came this wonderful tale? Here lies the special* interest for English readers. The poem, the fragments of which M. Bédier has edited, and the main contents of which he has, by the help of the translations, ingeniously essayed to restore, was written in England in Anglo-Norman. Whether Thomas was a Briton (he quotes the Welshman, Bréri, or Bleheris, as his source), or of Anglo-French birth, we cannot tell, but he was a writer of great skill and charm, a little over-fond, perhaps, of analysing the feelings of his characters, but undoubtedly a true poet.

Unfortunately we possess only fragments of his work. Of these by far the most important is that preserved in the Douce collection at Oxford. There is a second at Cambridge, and a third in the possession of a private collector at Turin. When M. Francisque Michel published his edition of the poems relative to Tristan (1835-39) he had access to two other frag. ments-one, in the Strasburg Library, perished in the flames of l'année terrible; the other, the property of the Rev. Walter 
Sneyd, cannot now be traced. All these represent, with some overlapping, the latter part of the poem alone; of by far the greater part M. Bédier has only been able to make a conjectural restoration, by the aid of the extant translations. Here we are fortunate; we have not only the English Sir Tristrem and the Scandinavian Tristan-Saga, but also the fine Tristan of Gottfried von Strasbourg, which, left unfinished, by a happy chance carries us precisely to the point where the original fragments begin.

M. Bédier devotes the first volume of his work to this reconstruction; in the second he enquires into the sources from which Thomas has drawn his poem. This second volume, written with an intimate knowledge of the subject, the fruit of many years' study, and with a grace and charm of style worthy of the best traditions of French scholarship, will have most interest for the general reader, while at the same time it raises questions of extreme importance for the critic. In M. Bédier's opinion all the extant versions of the Tristan legend, the work of Thomas and his translators, the poems of Béroul and Eilhart von Oberge, the two versions of the Folie Tristan, and the prose Romance, derive ultimately from one and the same source. That source was a poem superior alike in psychology and construction to any of its derivatives. The name of the author of this poetical chef d'cuvre has perished, but M. Bédier suggests that he probably lived in the first years of the Norman Conquest.

The theory is very fascinating and very tempting to our amour propre. The late M. Gaston Paris, who finally accepted this view, was decidedly of opinion that this proto-Tristan was English; but we must own that the comparative analysis of the incidents does not appear to us to point in this direction. We do not think M. Bedier has attached sufficient weight to the reference to Bréri. He admits that Bréri is identical with the Bleheris twice referred to in the Perceval as authority for stories connected with Gawain. Now in each case the story is a short episodic recital, not in any sense an elaborate poem. If Bréri was the authoritative source for the Tristan legend, and Thomas distinctly says he was, then that legend was not 
in the form of an elaborate and psychological poem. Again; is it possible that the incident of the surrender of Iseult to the lepers, an incident unparalleled in all Mediaeval literature for sheer unredeemed brutality, is a part of the same tradition as that which has preserved the gracious touch of Mark shielding his sleeping and fugitive wife from the rays of the sun? It seems more probable that there were from the first two distinct streams of tradition, in one of which Mark was a gentle, kindly figure, loth to believe ill of those he loved so dearly, and ready, even to weakness, to be convinced of their innocence; another in which he was cowardly, vindictive, and treacherous - the version followed by Thomas belongs undoubtedly to the former. Nor does M. Bédier quite grasp the problem of the messenger who summons Iseult to her lover's death-bed. What does Tristan need with a "host" there, where he is in his own home? The disappearance of Governal, who certainly ought to be the messenger, from the closing scenes of the poem, is a point difficult of explanation, and which should not be ignored.

Tempting as the theory is, we feel ourselves unable to accept the view so ably urged in these volumes; but nevertheless $M$. Bédier has given us a piece of work of great interest and real literary value, one which no future writer on English literature can afford to neglect.

Jessie L. Weston.

At the Back of the Black Man's Mind; or, Notes on the Kingly Office in West Africa. By R. E. Dennett, Author of "Notes on the Folk-Lore of the Fjort," etc. Macmillan \& Co., Igo6.

THIs is a most perplexing book. At first sight it seems a jumble of unrelated facts, and of speculations which one is tempted to class, with M. Van Gennep, ${ }^{1}$ as dignes de la Kabbale. The disjointed and fragmentary character of some chapters-which

${ }^{1}$ Revue des Idkes, 15 Jan., 1907 ; “ Un système nègre de classification." 
are, in fact, mere collections of undigested notes-adds to the difficulty of grasping the author's reasoning. Indeed, I am by no means sure that $I$ have grasped it; but his reasoning is to be carefully distinguished from his facts, and these-so far as apparent from his by no means lucid presentationare certainly valuable. His main contention, we gather, is that "concurrent with fetishism or Jujuism, there is in Africa a religion giving us a much higher conception of God than is generally acknowledged by writers on African modes of thought." This religion, to which Mr. Dennett gives the name of Nkitism, has, he thinks, been overlaid by Ndongoism (equivalent to what is usually understood by witchcraft and fetishism), and in great part forgotten. It was handed down in connection with certain formulae embodying what may be called a system of philosophy, theology, and ethics, which were taught to the people by their kings (Maloango) in the sacred groves. Much of this traditional law has evidently been lost, and the kingly office itself has fallen from its ancient estate. Maloango, the paramount chief of the Bavili tribes in Loango, was once tributary, along with Kakongo, to the Ntotela, or King of Kongo (Sao Salvador), but has been virtually independent for the last three hundred years-at least till the French took over the country in 1883 . The present chief, however, was never officially crowned,- a fact which, for various reasons, is to be deplored. But the bearing of these matters on native administration-not the least important of the issues raised by Mr. Dennett-does not come within the scope of this notice.

As we shall have occasion to point out later on, Mr. Dennett has failed to employ his excellent linguistic knowledge to the best advantage, for want of such acquaintance with other Bantu languages as would have enabled him to employ the comparative method. In the same way, one fancies, he does not perceive the real bearing and connection of many of his facts; which, indeed, I must confess, left me in a state of helpless bewilderment, till, fortunately, I lit on the clue supplied by M. Van Gennep, viz. MM. Durkheim and Mauss' article in L'Année Sociologique for 1903. This places the Bavili "Categories" (p. 108) in their true light as elementary attempts at classifying 
the phenomena of the visible universe. Here, as in the other cases, the Australians, who possess-or till recently possessedin a fairly complete form, customs and institutions which, among the Bantu, have fallen into decay, can elucidate many obscure points in our study of the latter. We are apt to forget that a classification of genera and species, and a sequence of cause and effect, which seem to us perfectly simple and obvious, are by no means so to children or savages. Even a person with no special scientific training would never suppose that a man could turn into a hyena, or that a leopard could become the parent of a crocodile, nor would he find it easy to realise the mental attitude of people to whom these things would seem quite natural. The leopard, says MIr. Dennett, "is looked upon as the mother of all animals [and] we cannot be wrong in saying that she is descended from Zambi through Xikamaci [Chikamasi] and her offspring Xikanga and Nxiluka, who are said to be the parents of an animal and a wooden figure" (p. 145).

Later on (p. 152), we read: "Zambici, in some of the stories, is spoken of as the mother of all animals, as if she were the immediate mother rather than the creator. This confusion is natural to degenerate people, who are apt to mistake the intermediate causes for the first cause." This is surely reversing the order of things. Such a conception belongs rather to a primitive than a degenerate stage of thought.

Mr. Dennett has not republished the etymological speculations of "The Bavili Alphabet Restored" (African Society's Journal, October, 1905), and I cannot help thinking, with M. Van Gennep, that he has been well advised. At the same time, it seems most probable that, as the last-named writer points out (Revue des Idées, Jan. 15, 1907), the "Categories" may give us the clue to the real meaning of the Bantu noun-classes, which some students were inclined to rank with things impossible to be known, while others seemed to lose themselves in fantastic conjectures. The statement that the first class contains nouns signifying persons, and the second names of trees, and so on, did not exhaust the facts, even as far as those classes were concerned, and the exceptions were too numerous to be treated as accidental. It is much to be desired that this investigation 
should be followed out on the lines indicated by M. Van Gennep.

Mr. Dennett evidently has a thorough knowledge of the Chivili language-otherwise the Loango dialect of Kongo (Fiote)-and here I am somewhat at a disadvantage in following him, as many of the words given by him are not to be found in the late Mr. Holman Bentley's Dictionary of the Kongo Language. ${ }^{1}$ This is, I think, not so much from any fundamental difference in the two dialects (since, where we can trace cognate forms, they are not very far apart) as from the fact that many of Mr. Dennett's words relate to matters which did not come within the scope of Mr. Bentley's inquiries-perhaps, in the case of the more archaic, to traditions already lost in Saó Salvador. He does not, for instance, give any words for "north" and "south," nor any names for the different winds, which play so large a part in the Bavili philosophy; whence, perhaps, we may infer that the Bakongo were not in the habit of paying much attention to the cardinal points, the fixed directions of sunrise and sunset being sufficient for all practical purposes. Many of the Chivili sentences quoted by Mr. Dennett are undoubtedly very ancient, and would be unintelligible unless explained by a native-as is often the case with proverbs, songs, and other traditional matter. Thus, "the valley of the fly and the mosquito hand in hand" (pp. 12, 118), is rather a gloss than a translation of Bulu Zimbu Chikoko (Bulu=valley; chikoko is evidently an adverbial form derived from $k o k s=$ hand; $z i m b u$, plural of $m b u=a$ mosquito). This is probably also the case with the native explanations of the symbols on pp. 71-73.

It might not be fair to demand from every student of any given language a knowledge of comparative philology; but a little acquaintance with some other Bantu languages would have shown Mr. Dennett that some, at least, of his etymologies are scarcely

${ }^{2}$ It is much to be regretted that Mr. Dennett should have chosen an orthography which must obscure the identity of his Chivili words for all students of the Bantu languages. I have ventured, except in direct quotation, to restore them to a form in which they are more generally recognisable. His use of $x$ is particularly trying, from its Portuguese associations, even though it may not suggest the Zulu lateral click ! 
tenable : e.g. "Mwici contains the root $\mathrm{Mu}$ (for Mbu = the sea)." The mu in mwisi (Bentley: mwixi=smoke, haze, etc.), is the prefix, and the word is identical with the Zulu umusi, Swahili moshi, and Herero omwise. In Nyanja the prefix is atrophied, and the word appears as $u t s i$, and in other languages (as in Konde ilyosi and Kamba jioki), we find a different prefix. Neither is it at all probable that the prefix $m u$ has anything to do with $m b u=$ the sea, if only because the $m$ in $m b$ is a nasalising of the labial, and not likely to be found without the latter.

Again, the derivation of $k a$ zila, applied to prohibitions, from nzila $($ njila $)=a$ road, appears doubtful when we remember the Zulu verb zila, meaning "to abstain from, as from certain words or actions, as from certain kinds of food" (Colenso's Dictionary). In Ronga, yila (evidently the same word), and in Ila (the language of the people usually called Mashukulumbwe in N.W. Rhodesia) $k u$ zhila, mean "to be forbidden, tabooed." It may also be pointed out that in all Bantu languages we find many identical words (or rather, one should say, groups of sounds) of different meanings, and, probably, different etymologies. The identity may have been produced by phonetic decay, of which we see the ultinate result in the hundreds of identical monosyllables in Chinese; in any case, it is highly improbable that the Zulu gula =" to be ill" has any connection with the Nyanja word gula, which means "to buy," or the Kongo nika = "to grind," with Zulu nika = "to give." Thus, for instance, it is possible (though one would be sorry to dogmatise on the subject) that the different meanings of kanga (see p. 114) have nothing to do with one another; and, if so, all interpretations based on the contrary hypothesis naturally fall to the ground. How Nyambi (p. I16) means "the spirit or personality of the four," it is difficult to see. $Y a$ is "four"-but Mr. Dennett gives " $i a=$ to be" as one of the constituents of the word-and he cannot have it both ways.

The matter contained in Mr. Dennett's book is so abundant, and of so varied a character, that a full discussion within the limits here imposed would be impossible. All that can be done here is to add a few comparative notes.

The name Nyambi seems, from its occurrence alternately with Nzambi, among tribes both north and south of the Bavili, 
to me (pace Mr. Dennett) to have the same force. We find it used by the Duala, Benga, and Mpongwe. The Hereros believe in a Supreme Deity, Njambi Karunga, who is distinct from the ancestral spirits (ovakuru), and does not, like them, receive worship and sacrifice, though invoked under stress of calamity. In Angola, we find $\mathrm{Nzambi}$, and also a distinct being, Kalunga, a personification of Death. On the other hand, the Barotse pay stated devotions to Nyambi at sunrise and sunset-see the remarkable account given in the journals of the late M. Coillard (Coillard of the Zambesi, pp. 345-8).

Mr. Dennett asks (p. 163): "And can NGO [the leopard] then be the sacred animal of not only the Kongo people, but of all the Bantu?" This is certainly a subject worth investigating; we find scattered indications that such may even have been the case with the Zulus. The name ingze $(=n g o)$ is seldom heard, being counted unlucky; the animal is usually called isilo, which really means "a wild beast" in general, and isilo itself is one of the royal titles of great chiefs. The leopard's skin, too, could only be worn by chiefs. Again, the name nyalugwe, used in Nyanja, is probably substituted, for reasons connected with hlonipa, or, to use Mr. Dennett's word, china, for some cognate form of ngo.

A curious parallel to the ematon of the Bini (p. 194) is described by Livingstone (Missionary Travels, ch. xii. ${ }^{1}$ ). At Lilonda, the residence of the deceased Barotse chief Santuru, he found "a grove . . . in which are to be seen various instruments of iron just in the state he left them. One looks like the guard of a basket-hilted sword; another has an upright stem of the metal, on which are placed branches worked at the ends into miniature axes, hoes, and spears ; on these he was accustomed to present offerings, according as he desired favours to be conferred in undertaking hewing, agriculture, or fighting."

Lastly, the Bini folk-tale on p. 230 is a variant of one found both in Bantu and Negro Africa, in several different versions, one being given by Mr. Dennett himself in Folklore of the Fjort. The theme usually is that the Hare and the Elephant agree to kill their mothers in time of famine, and the Elephant does so, while 'P. 191 in Ward \& Lock's edition. 
the Hare backs out of his share in the agreement. In a Bemba story the protagonists are the Hare and the Lion; in a Lusiba one, the Hare and the Leopard; and the Wakinga (North-East Nyasa) tell the tale of two men. Perhaps the story in "Cunnie Rabbit," where Spider and Leopard agree to eat their children, but the former cheats, might also be reckoned as a variant. I hope, some day, to find leisure for a comparative study of this tale in its various African versions.

A. Werner.

The Khasis. By Major P. R. T. Gurdon, I.A., Deputy Commissioner, Eastern Bengal and Assam Commission, and Superintendent of Ethnography in Assam. London: David Nutt. 1907.

This is the first of a series of monographs on the wilder tribes of Assam which was projected by Sir B. Fuller, the late Lieutenant-Governor of the province. The author, who is superintendent of ethnography and editor of the series, is thoroughly familiar with this interesting people, understands their language, and as district officer has visited every part of the beautiful country which they occupy. The Khasis, or, as they used to be called, the Cossyahs, to the number of 176,000, inhabit what is known as the Khasi and Jaintia Hill district in Assam. As regards their ethnical position, Major Gurdon rightly connects them with the Mon-Anam race, which is supposed to have occupied the Malay Peninsula and a con. siderable part of Eastern India in prehistoric times. In support of this he refers to three points of resemblance: a peculiarly shaped hoe found among the Khasis, the Nagas, and the aborigines of the Malay region and Chota Nagpur; the sleeveless coat worn by Khasis, some Nagas, and by Mikirs; and the habit of erecting memorial stones, common to Khasis, Mikirs, Magas, and the Ho-Mundas of Chota Nagpur. These alone do not prove the common origin of these tribes, but they agree with the linguistic evidence. 
Out of the mass of interesting material collected in this monograph I can refer only to a few of the more important points.

In the first place, Sir C. Lyall's excellent summary shows that "their social organisation is one of the most perfect examples still surviving of matriarchal institutions, carried out with a logic and thoroughness which, to those accustomed to regard the status and authority of the father as the foundation of society, are exceedingly remarkable. Not only is the mother the head and source, and only bond of union, of the family; in the most primitive part of the hills, the Synteng country, she is the only owner of real property, and through her alone is inheritance transmitted. The father has no kinship with his children, who belong to their mother's clan; what he earns goes to his own matriarchal stock, and at his death his bones are deposited in the cromlech of his mother's kin. In Jowai he neither lives nor eats in his wife's house, but visits it only after dark. In the veneration of ancestors, which is the foundation of the tribal piety, the primeval ancestress and her brother are the only persons regarded. The flat memorial stones set up to perpetuate the memory of the dead are called after the woman who represents the clan, and the standing stones ranged behind them are dedicated to the male kinsmen on the mother's side." In conformity with this social arrangement goddess worship is predominant, and the founder of their civilisation is a culture heroine.

Next come the "memorial" stones rightly so called, many of which were unhappily overthrown in the recent disastrous earthquake. Major Gurdon shows that they closely resemble those of Chota Nagpur, which are familiar to us from the accounts by Colonel Dalton and Dr. Ball. He adopts the following classification of them: $(a)$ those which serve as seats for the spirits of departed clansfolk on their way to the clan cromlech; $(b)$ those erected to commemorate a parent or some other near relation; (c) those which nuark tanks, the water of which is supposed to cleanse the ashes and bones of those who have died unnatural deaths; (d) flat table-stones, often accompanied by menhirs, which are not devoted to the dead, 
but serve as seats for weary travellers. His description of the mode of erection of these stones, and of the death rites of the tribe, is full and interesting. Most of the leading facts have been already given by Sir H. Yule, Major Godwin-Austen, and Mr. Clarke.

As regards folk-lore, the account of their rules of taboo is valuable, and in a special appendix will be found a description of their curious mode of divination by egg-breaking. He gives a few folk-tales out of a large collection, which, it may be hoped, will soon be published. Those that he has printed are not very important. One, which ascribes the spots on the Moon to the Sun, who threw ashes at him because he tried to commit incest, is like a Hindu tale. In another we have the myth of the separation of Heaven and Earth. Heaven drew up the Earth by his navel-string; this the people cut where it was fastened to a hill, and "it was since that time that heaven became so high." They have a Flood legend, but the account of it is vague.

A most remarkable superstition is that connected with the Thlen, a gigantic snake which demands human victims, and for whose sake murders have been committed in fairly recent times. A brave man once destroyed the Thlen of his day by inducing it to open its mouth, into which he promptly dropped a lump of red-hot iron. The beast was then cut up, and the hero directed the people to eat its flesh. If this order had been obeyed the world would have been free of these monsters; but, unhappily, one small piece of the meat remained uneaten, and from this the breed was reproduced. The Thlen attaches itself to property, and a condition of the owner's prosperity is that the monster shall receive blood. This is extracted by the murderer from the nose of his victim by a bamboo tube, and then offered to the Thlen. I cannot quote any exact Indian parallel to this belief. The subject of the Thlen deserves careful investigation.

The present volume has been printed in England, and its format is in pleasant contrast to that of most of the publications of the Government of India. It is illustrated by some excellent coloured plates from sketches by Miss Scott-O'Connor and the 
late Colonel Woodthorpe, besides several good photographs. If any criticism may be offered on this excellent monograph, I would suggest that the bibliography is unsatisfactory. It does not give details of dates of publication or of editions, and it is quite useless to refer to papers in publications like the Journal of the Asiatic Society of Bengal without exact reference. It is also imperfect, because it omits the valuable papers by GodwinAusten and Clarke in the Journal of the Anthropological Institute. Lastly, in his "Table of Contents" Major Gurdon should distinguish folk-lore from folk-tales, and a monograph of this kind should certainly be provided with a map.

W. Crooke.

The Natives of British Central Africa. By A. Werner. A. Constable \& Co. Ltd. Igo6.

Miss Werner's contribution to the series of The Native Races of the British Empire is one of great charm, as well as of anthropological interest. Her personal experiences among the Yao and Anyanja, and her enthusiasm on their behalf, impart a feeling of intimacy which no amount of knowledge gained from books can give. British Central Africa is technically the Protectorate of that name, comprising only the western and southern sides of the basin of Lake Nyassa. In the minds of most readers it will perhaps have a larger connotation. Even in the former case, it is too wide a term for the real subject of this book, which is mainly concerned with the two tribes just named, only touching the others incidentally. But the Yao and Anyanja are sufficiently important to deserve a book to themselves.

They are, according to their traditions, and probably in fact, cognate tribes. The Anyanja were a peaceful people, into whose territory on the Shire Highlands the more warlike Yao, driven by pressure from the north, broke not long before the middle of the last century. The Yao came from the Portuguese possessions on the eastern side of Lake Nyassa, where many of them still dwell. They subjugated the Anyanja, and settling at length side by side and intermarrying with them, began a process of coalescence 
into one people which is still going on. Hitherto we have been dependent for most of what we know of the Yao and Anyanja upon the Rev. Duff Macdonald's Africana, a book invaluable for the student of the Bantu race. But Macdonald, with all his merits, was nothing of an anthropologist. It was quite time that his book should be-not superseded : that is probably impossible, but-supplemented by some one who knows the problems anthropologists are trying to solve, and is able to assist in so doing. Although Miss Werner addresses primarily an audience of a popular character, her wide knowledge of the Bantu, her comprehension of the scientific issues, her sense of proportion, and her clear and pleasant style, combine to render her work useful to more than "the general reader."

The book opens with a geographical account of the country, its climate, fauna, and flora. The authoress passes on to a list of the tribes, and an account of their physical characteristics, dwelling chiefly on those of the Mang'anja and Wayao. She carefully discusses their artificial deformities, (keloids, the perforation of the lip for a plug, and the filing of the teeth), and their fashions in hairdressing. Then come two important chapters on Religion and Magic. After this native life, from birth to death and burial, comes under review. Arts and industries, the language and folklore, music and dancing, follow. The tribal organisation and government are explained, and finally the history and migrations, so far as we know them from civilised records, or can infer them from the traditions of the natives, are traced. It will thus be seen that the entire ground is covered, and Miss Werner is able from her own experience constantly to add details, or to give explanations which throw considerable light on the subject. It is true that exact references to authorities are dispensed with, according to what I think the indefensible plan of the series. But the want of them is, to some extent, compensated by the security that the reader feels that where the author is quoting she always has her own personal knowledge of the tribes chiefly described in the background to satisfy her that the statements quoted are accurate, and thus though the information may be conveyed by quotation, it is, to some extent at any rate, to be received on her personal authority. 
Among the many interesting questions considered, I will only refer to one. We were able to gather from Macdonald's work that the Yao and Anyanja reckoned kinship through the mother. Miss Werner shows that they are divided into exogamous totemclans, though she is unable to give anything like a list of those clans. I hope she has correspondents in the neighbourhood of Lake Nyassa who are able to supply her with this information, and to assist in the explanation of the clan-names, and the usages and superstitions relating to the totems. This is an urgent matter, as the missionaries and other influences of "civilisation" will, it is to be feared, very soon obliterate all memory of the old organisation and beliefs. Some of the Anyanja tribes are passing into the patrilineal stage, and what is most interesting is that they are doing so along precisely the same road as that adopted in German South-west Africa by the Herero. They have adopted a system of agnatic descent, and carry it on side by side with the older reckoning through the mother. The quotation Miss Werner makes from Bishop Maples-" the mother preserves to her offspring the tie of kinship, the father that of blood"-is incomprehensible to me. Mr. Thomas, in his book on Australian kinship, draws a distinction between blood and kinship, which may or may not be valid. But that distinction does not help us here. Bishop Maples' words may convey some subtle difference which a further investigation of the tribes he refers to may disclose. The fact of two distinct Bantu peoples at a distance from one another of nearly fifteen hundred miles as the crow flies, right across the continent, adopting the same device to smooth the passage from motherright to fatherright should help in the solution of more than one anthropological problem. Is it too late to recover the details of the ingenious arrangement which Bishop Maples was the first to make known? Perhaps the author can secure them.

The illustrations, as a whole, are excellent. Though some are rather too small, many of them are of exceptional clearness and beauty, and effectively assist the reader to realise the various types of humanity and the customs described.

E. Sidney Hartland. 
Les Fontaines des Genies (Seba Aroun), Croyances soudanaises A Alger. Par J. B. Andrews. Alger, 1903. 8, pp. 36.

There are at Algiers a number of West African negroes of various tribes-Hausa, Bambara, etc.-each of which is organised into a religious society, called Dar. These societies possess houses inhabited by their chiefs, which also serve as centres of the cult and contain the religious emblems. Each Dar has its assemblies of men and women, the former ruled by five kebir, the latter by a single hounia, and it is the latter who is most closely associated with the djinn, of which there are many. There are seven fountains, but the correspondence with the number of Diar is accidental, for each fountain has its special djinn, though the cult of each dar is not restricted to a single spirit.

Sacrifices are an important part of the cult, and a common explanation of the ecstatic state of the votaries, provoked, as is commonly the case, by dancing, is that they are possessed. Mr. Andrews gives a long list of names of djinn, and it would have been interesting to learn more as to the origin of the names; they are represented as divided into nations and tribes, and have the reputation of causing diseases as punishments for affronts offered to them. There is also some account of the musical instruments employed by the negroes, probably imported by them, and a few specimens of their melodies. The work is useful, but a comparison with the home customs of the tribes in question would have increased its value.

N. W. ThOMAS.

The Rymour Club, Edinburgh, Miscelraned. Part I. March, 1906.

WrTH a membership of forty-nine, this club has begun, not only to collect, as set forth in the objects of the society, but also to publish ballads, lyrics, and other rhymed material, and ballad and other tunes, etc., more particularly such as illustrate 
Scottish dialect, character, manners, and music in former days. Its members are almost all resident in Edinburgh, but it has adopted an ingenious method of calling attention to its existence and ensuring the activity of collectors: the list of corresponding members contains thirty names, and they will doubtless feel it incumbent upon them to further the objects of the society in a way that an ordinary subscriber would not. This issue of Miscellanea contains four contributions: children's rhymes and rhyme-games, from the collection of one of their corresponding members in New Zealand; the ballad of "Jack Munro" (with music); the original version of "Within a Mile of Edinboro' Town"; and two northern bothy songs. The Folk-lore Society is always ready to give its blessing to local effort. In the present case it does so with especial pleasure, because the infant society is evidently a vigorous child, which will not die of inanition. The secretary is Mr. A. Reid, F.S.A.Scot., The Loaning, Merchiston Bank Gardens, Edinburgh, and the subscription five shillings.

In Malay Forests. By George Maxwell. Blackwood. 1907. THIS little book-it is small in size and modest in appearance, although it runs to $306 \mathrm{pp}$.- - contains much that is of interest for members of the Folk-lore Society, for it is the work of a thoroughly good sportsman who is more than usually well versed in jungle magic. This combination is unfortunately not a very common one, but in this instance, at all events, it is attended with the happiest results, the folk-lore details giving a sense of completeness to the pictures of big game shooting which is as pleasant as it is rare. The stories-fifteen in number-though not all recorded here for the first time, are capitally told in terse, clear, vigorous English. The sportsmanship is of the right kind, and the folk-lore is not only interesting and accurate, but gives valuable variations of, and parallels to, many of the spells and ceremonies employed by the Malays in hunting the bigger wild animals. Incidentally, in most of these tales, we get 
vivid glimpses of the Malay pawang, or magician, a figure now fast disappearing under the continual increasing pressure of Islamic practice, but one of whom we would fain know more. "A Tale by the Wayside" contains a selection of mouse-deer stories, the mouse-deer being the "Brer Rabbit" of the Peninsula. "A Deer-drive" describes the "make-believe" by neans of which the deer are driven into the toils. The horrible end of "A Were-Tiger" is a reminiscence of the darker days of the Peninsula, before the strong arm of the British Government had destroyed the power once so arrogantly claimed by the Malay chiefs, to slay men at pleasure without being asked the reason. If we were requested to name the best of these stories, we should be inclined to choose "The Pinjih Rhino," which contains a very good account of a spiritualistic seance, at which permission to slay the rhinoceros in question was extracted by dint of sheer perseverance from the spirits of the jungle.

The book might have been better arranged, and would have been greatly helped by illustrations; and the addition of a few more references to its sources would improve the appendix. There are a few slight misprints and errors, which we give in order that they may be avoided in a subsequent edition. We may mention "Næmorhedus" for "Nemorhedus" (pp. 168, 169), "Malin" for "Malim" (p. 122), "Pinjlh" for "Pinjih" (p. 303), "Biaua" for "Biawak" (p. 295), and "Cocoa nut" for "Coconut" (passint). The transliteration of the Arabic phrases might be here and there improved, and there are one or two slips in translation. "Voice Folk" (p. 1 78) (orang bunyi, i.e., sembunyi) should be "Invisible Folk," and Unta (p. 55), in conjunction with sirih and pinang, cannot mean "camel." We feel doubtful, moreover, as to the rendering of Salam di rimba by "Peace of the Forest"; and we have always understood that it is with his forefeet, rather than his hindfeet (p. 238), that the buck does his tapping in rutting-time.

Walter W. Skeat.

Books for Review should be addressed to THE EDITOR OF Folk-Lore, c/o DAVID NUTT, 57-59 LONG ACRE, LONDON.

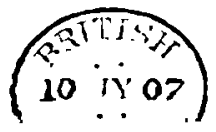

